\title{
Safety of Maritime Transport in the Baltic Sea
}

\author{
Jacek Caban ${ }^{1, *}$, František Brumerčík $^{2}$, Ján Vrábel $^{3}$, Piotr Ignaciuk ${ }^{4}$, Wojciech Misztal ${ }^{1}$, and \\ Andrzej Marczuk ${ }^{1}$ \\ ${ }^{1}$ University of Life Science in Lublin, Faculty of Production Engineering, 20-612 Lublin, Poland \\ ${ }^{2}$ University of Žilina, Faculty of Mechanical Engineering, Univerzitná 8215/1, 01026 Žilina, \\ Slovakia \\ ${ }^{3}$ University of Žilina, Faculty of Operation and Economics of Transport and Communications, \\ Univerzitná 8215/1, 01026 Žilina, Slovakia \\ ${ }^{4}$ Lublin University of Technology, Mechanical Engineering Faculty, 20-618 Lublin, Poland
}

\begin{abstract}
The maritime economy is particularly exposed to danger due to the environment of its operations. These risks result from deliberate actions, as well as incidental (hydro-meteorological conditions, mechanical, etc.). These are the threat dependent and independent of human e.g. environmental, safety health and life of humans or belongings. In spite of attempts to limit the risk of danger, it is impossible to completely eliminate it. May be helpful here all kinds of security systems, alarm, emergency, legislative and educational of ship owners and crews to the defence activities. The article presents some aspects of the state of transportation safety in the Baltic Sea Basin as well as undertaken the attempt to analyse the security state of this sea area.
\end{abstract}

\section{Introduction}

Sea and water ways are mainly used for world-wide goods transportation [1]. Maritime transportation plays a significant role in the integrated transportation system, especially in international trade system [2]. Around $90 \%$ of world trading is carried out by the shipping industry [3]. Safety is a crucial factor due to the fact that various accidents like ship collisions and groundings often result in great economic loss, fatalities and the environmental contamination [2]. The main directions of movement of goods by sea are borders linking Asia and Europe, Europe and North America, as well as the route connecting Asia with North America.

Shipping is also a highly regulated domain, and regulations have been reinforced in the last two decades [3]. The main principles underlying shipping regulations are harmonized national rules based on international conventions and resolutions given by the International Maritime Organisation (IMO) [4]. At the level of the European Union (EU), the European Commission (EC) translates the regulations, determined at the IMO, into binding laws, with the support of the European Maritime Safety Agency (EMSA) [5]. Further, the rules are adapted to regional conditions by the Baltic Marine Environment Protection Commission (Helsinki Commission, HELCOM), an intergovernmental organization of nine Baltic

\footnotetext{
*Corresponding author: jacek.caban@up.lublin.pl
} 
coastal countries and the EU [6]. In the globally orientated maritime safety regime, the regional role of the HELCOM in the Baltic Sea is significant [7]. The aim of HELCOM is protect the marine environment of the Baltic Sea from all sources of pollution. It collects data related to maritime traffic, accidents and oil transportation, gives recommendations related to maritime safety and pollution from ships, and coordinates multilateral response in case of major maritime incidents [7].

Since our inception of maritime transport are also present factors causing all kinds of threat in this sector of transport. Therefore, can assume that the dangers accompanying in maritime transport have are continuous in time, impossible to the eliminate entirely, and also amenable to changes in parallel with the development of civilization. The International Convention for the Safety of Life at Sea (SOLAS) of the IMO recommends Vessel Traffic Services (VTS) for areas in which the volume of traffic or the risk of accident is high [8].

Maritime safety is referred to as safety of life, health and property from operating and environmental hazards, and the safety of the marine environment against pollution which are a by-products of human activities at sea. The maritime economy is particularly exposed to danger due to the environment of its operations. These risks result from deliberate actions, as well as random (weather conditions, the mechanical elements state, etc.). At the same time, it is a collection of punks logistics necessary for the functioning of the global economy. Nowadays it is difficult to imagine international trade without the participation of the maritime transport.

The nine bordering countries with Baltic Sea Area and approximate catchment and main sub-basins indicated was shown in Fig. 1.

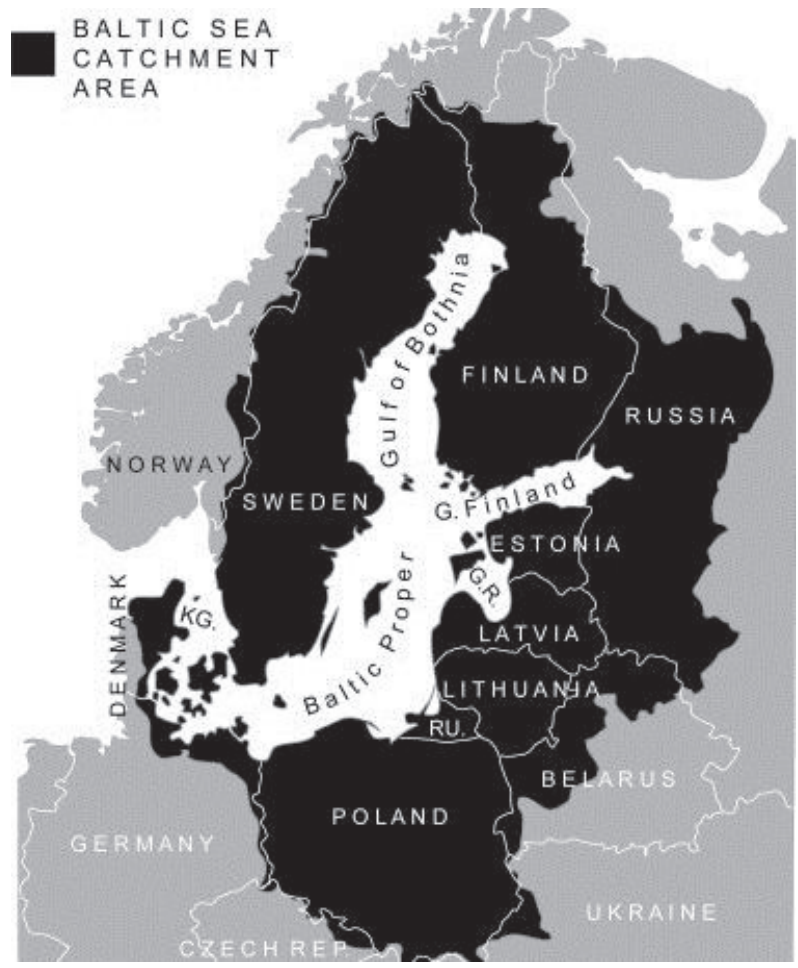

Fig. 1. Baltic Sea Area with coastal countries, approximate catchment and main sub-basins indicated. KG - Kattegat, RU - Russian enclave of Kaliningrad, G.R. - Gulf of Riga, G. Finland - Gulf of Finland. Note that Gulf of Bothnia consists of two major parts - Bothnian Bay in the north and Bothnian Sea in the south. Source: [9] 
This countries jointly suffer from environmental pollution, and are responsible for, the degraded state of the sea. The primary threats caused deliberately by a man is piracy and maritime terrorism. The events caused by factors independent of a man is mainly: the disaster of ships and other objects resulting from the weather conditions, as well as oil spills from ship. These events are often associated with incurring a real losses and the require take the appropriate actions.

The article presents some aspects of transport security on the Baltic Sea and an attempt was made to analyse the security situation of this sea area. One objective of the study is to show the causes of maritime accidents in the Baltic Sea.

\section{Factors affecting the safety of sea transport}

Dynamic development of maritime transport in the Baltic Sea region is stimulated by a variety of factors [10]. These factors - both external and internal, that is, inter-Baltic, and market and non-market, transport and non-transport - affect with different strength the size and structure of carriage by sea [10]. The Baltic Sea basin is relatively small and closed, and thus particularly sensitive to threats [11]. The Baltic is a shallow sea, its mean depth being 50 meters. While maritime transport is of vital economic importance to the Baltic Sea Area, challenging winter navigation conditions pose additional hazards to ships operating in these waters [12]. The increase in migration of people and the circulation of goods by sea has caused an increase in the volume of traffic on the routes, while technological progress has made it possible to build vessels with a large carrying capacity. According to IMO [13], the Baltic Sea Area has some of the densest maritime traffic in the world [14].

Several maritime accidents tragically demonstrate that an accurate assessment of the situation as well as timely and right decisions both aboard the emergency vessel and by the Search and Rescue (SAR) authorities are of paramount importance when attempting to save the people aboard and for ensuring the safety of the vessel itself [15]. Accidents where inadequate information and communication about the vessel's condition have been identified as factors needing improvement are for instance the flooding and foundering of the Abigail H [16], the grounding and capsizing of the Costa Concordia [17] and the grounding and flooding of the Commodore Clipper [18] or MS 'Jan Heweliusz'.

One area where improvements are considered necessary by especially SAR operators is the communication and information exchange between vessel crew, SAR operators and other relevant parties in maritime distress situations [15]. The importance of shared situational awareness and the quality of information in emergency situations is also stressed by Luokkala and Virrantaus [19] and Seppänen and Virrantaus [20], who highlight the importance of narratives in information sharing.

Every ship, both passenger and cargo is a potential threat to the environment, as fuel and cargo of all kinds can get out of it into the sea. The presence of chemicals in the marine environment contributes to the imbalance of the sea's health and life, as well as reduces the aesthetic of the marine environment [11]. Accidents that happen during transport on shipping routes are difficult to predict. Therefore, sea transport is characterized by a high potential of danger [21]. In the face of these problems appeared the necessity of regulating administrative legislation as well as technical and quality standards, the aim of which is to protect the life and the marine environment. Until recently, there was no necessity, and the ability to assess the level of threats at sea. Only since the 50s of last century, when significantly increased transport of dangerous goods, particularly oil and gas, extremely increased threat to the marine environment [22]. The best measure of safety of navigation on a particular basin are data about accident rates of ships [23]. On the basis of the HELCOM [24] report in the year $201244 \%$ of the accidents took place in ports, $35 \%$ in the open sea, and $14 \%$ occurred during the approach to port and $7 \%$ of accidents were 
unidentified. In the years 2009 to 2015 on the Baltic Sea area there were near 439 accidents.

Due to the civilization and structural development of economy, factors threatening the security of maritime transport are also changing. Figure 2 shows the causes of accidents in the maritime transport sector in the years 2009 to 2015.

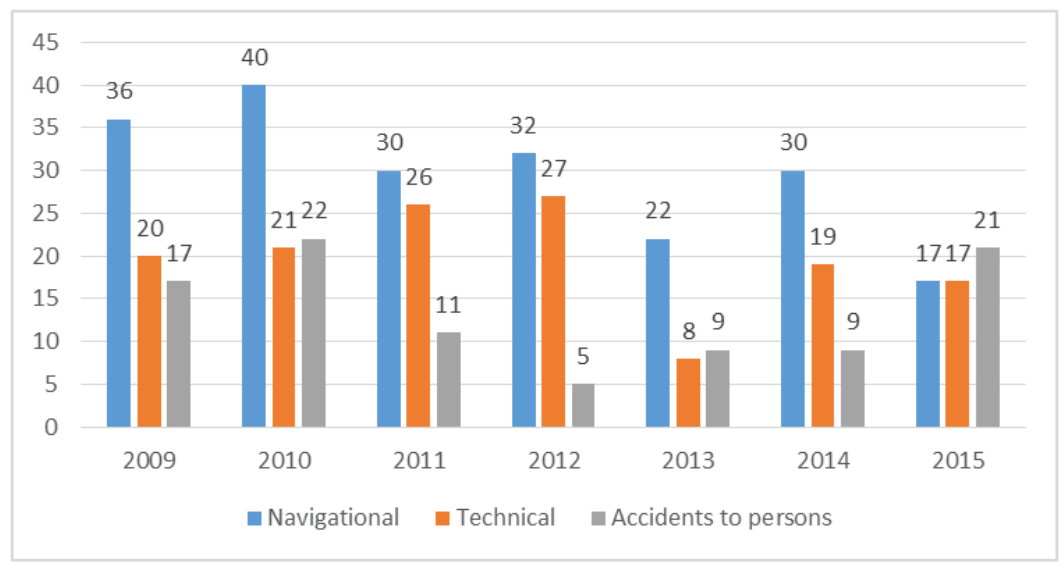

Fig. 2. General classification of types of maritime accidents occurring in the years 2009 to 2015 . Source: compiled on the basis of the [25-27]

The largest group of accidents are accidents of the genesis of navigation, the decisive factor in the advantage of this type of accidents are caused by human factors (errors in reading the location, bad training of the crew, etc.), and possible malfunction of the navigation instrumentation. A false sense of security "guarded" by electronics (radars equipped with ARPA, Automatic Identification System AIS, electronic maps, etc.), results in a fairly rapid growth of maritime accidents [23]. Lowering the vigilance of the navigator takes place on the open waters. Since 2009, the number of accidents decreased, except for technical reasons, that may be caused by cutting production costs and lowering standards of components implementation.

Figure 3 shows in detail the number of accidents which occurred for reasons of navigation.

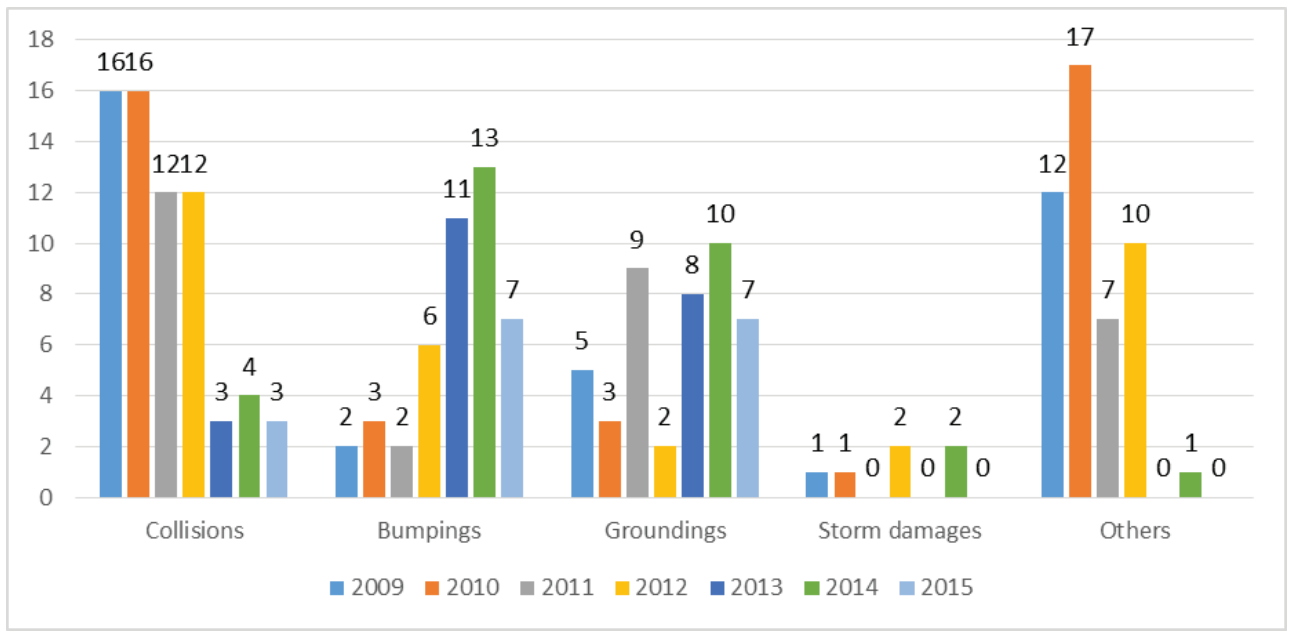

Fig. 3. Detailed classification of accidents due to navigation causes in the years 2009 to 2015. Source: compiled on the basis of the [25-27] 
Navigation accidents can be divided into several main groups, the largest ones, consisting of collisions, bumpings, groundings and storm damages. The largest number of collisions took place in 2009 and 2010, bumpings in 2013 and 2014 as well as grounding in the year 2014 and 2011. The largest number of others accidents was in 2010. As you can see in the graph (Fig. 3), the least navigational incidents occurred in 2015.

Figure 4 shows in detail the number of accidents which occurred due to technical reasons.

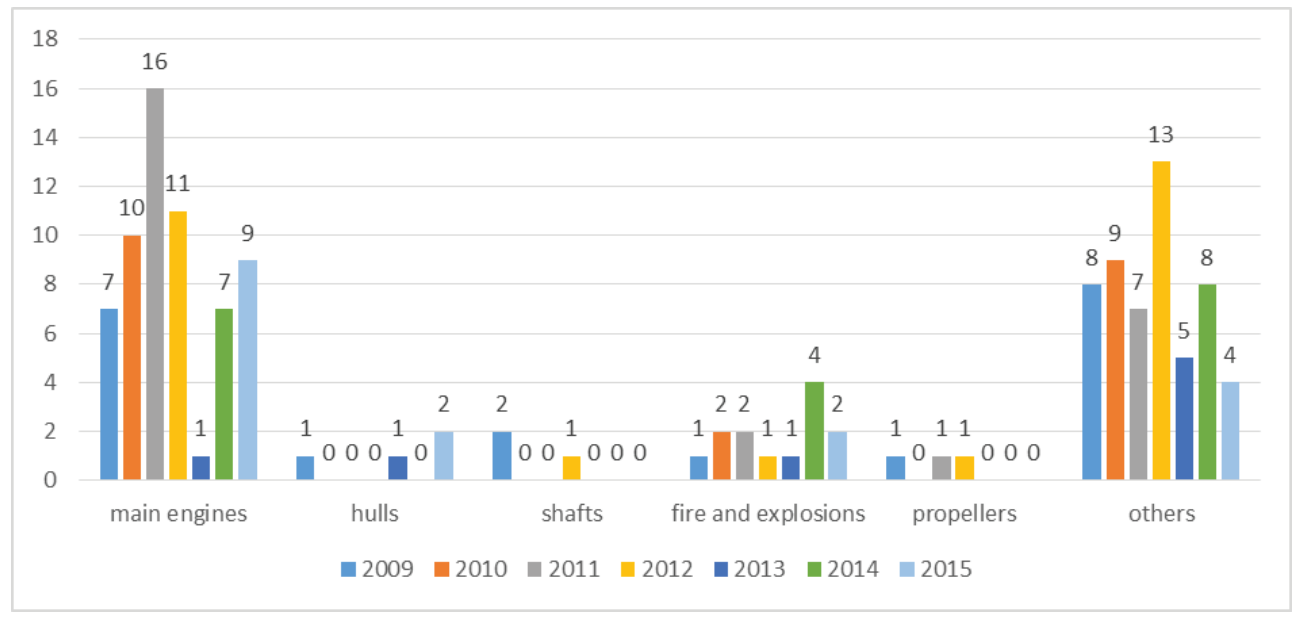

Fig. 4. Detailed classification of accidents due to technical reasons occurred in the years 2009 to 2015. Source: compiled on the basis of the [25-27]

The most common causes of accidents due to technical reasons are main engine failures. The largest number of accidents reported in the year 2011, this number dropped significantly in the year 2014. Accidents due to unsealing hulls, damages to drive shafts and propellers, and fires are relatively rare compared to the damage to engines which are clearly the predominant factor.

Figure 5 shows the detailed classification of maritime accidents caused by human factor.

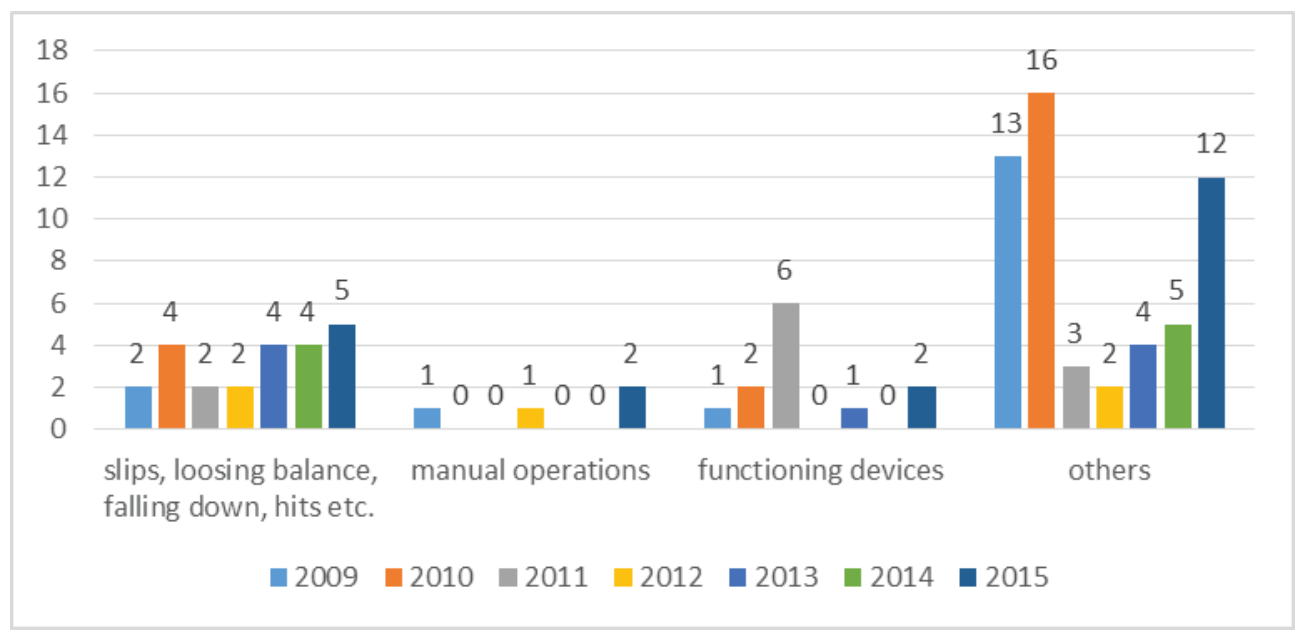

Fig. 5. Detailed classification of accidents caused by human factor in the years 2009 to 2015. Source: compiled on the basis of the [25-27] 
The number of marine accidents caused by human factor significantly decreased in the year $2010-22$ accidents and $2015-21$ accidents. Random accidents such as slip or loosing balance are at a similar level in view of the difficulty of eliminating these types of events that occur in an uncontrolled way. Most of the accidents caused by devices in services were reported in the year 2011, and in 2012 they were eliminated, but in 2013 was 1 and 2015 2, of this type of accidents. The largest number of other reported accidents was in 2010. This type of accident is the highest in all the years analyzed.

\section{Conclusion}

To assess the value of the operating conditions is used a number of approaches, due to the fact that in practice there are different circumstances allowing (or not) the application of certain methods [28]. Ensuring the safety maritime transport is both a regional and international issue. Particularly important are safety issues during cargo handling in ports and transport terminals [29]. The above mentioned development of transport applications depends on the creation and precision of digital maps [1], a specially for transport safety. All activities protecting the marine environment and human life should be encouraged and supported. The increased number of sailings on maritime routes endanger the environment and causes all sorts of accidents or collisions. An important link in the fight against the threats posed by human activities at sea are maritime safety systems. The latest telecommunication solutions allow you to coordinate the activities undertaken by various institutions, created to ensure safety in the area of environmental protection, all sorts of accidents at sea lanes as well as in the maritime terrorism.

In the analysed period (2009-2015), in the Baltic Sea occurred nearly 439 accidents. On the basis of the analysis, It has been shown that the largest group of accidents are accidents of the genesis of navigation, followed by technical and the last is accidents to persons. It has been shown, that the number of accidents related to people significantly decreased in the year 2012. The lowest number of technical accidents took place in 2013 (22 accidents). Moreover, it has been demonstrated that most of the causes of accidents caused by equipment operation occurred in 2011, which in 2012 they were eliminated. The most common cause of accidents due to technical failures were the main engines. In the category of navigational accidents it has been shown that the greatest number of collisions took place in 2009 and 2010, bumpings in 2013 and 2014 and stranding in 2011 and 2014.

In conclusion, it should be noted that there are a lot of components threatening the safety of sea routes, as well as degrading the environment. By pursuing comprehensive efforts to raise the level of safety in maritime transport it is possible, however, to reduce the risk of these threats. These include a.o. all kinds of alarm systems, rescue, tailored legislative conditions for the preparation of ship-owners and crews of ships for defensive action.

This work was carried out in partnership between University of Life Sciences in Lublin and University of Žilina, as well as Lublin University of Technology and supported by the Slovak Scientific Grant Agency of the Slovak Republic under the project No. VEGA 1/0077/15.

This paper is supported by the research project "From horse-drawn railway to intermodal transport" within Visegrad Fund. 


\section{References}

1. A. Kalasová, L. Palicka, Promet - Traffic \& Transportation 19, 2, 121-128 (2007)

2. J. Zhang, X. Yan, D. Zhang, S. Haugen, X. Yang, Safety Science 63, 157-167 (2014)

3. C. Chauvin, S. Lardjane, G. Morel, J.P. Clostermann, B. Langard, Accident Analysis and Prevention 59, 26-37 (2013)

4. S. Kristiansen, Marine safety - Background, A. Molland (Ed.), The Maritime Engineering Reference Book, Butterworth Heinemann, Chapter 11, 786-875 (2008)

5. European Maritime Safety Agency (EMSA), Quality Shipping, Safer Seas, Cleaner Oceans. Lisbon, Available online: http://www.roodbovengroen.com/website/ managedMedia/mediaItem/159.pdf (2009)

6. B. Hassler, Maritime Policy Management 37, 489-503 (2010)

7. P. Haapasaari, I. Helle, A. Lehikoinen, J. Lappalainen, S. Kuikka, Marine Policy 60, 107-118 (2015)

8. International Maritime Organization (IMO), Vessel Traffic Services, Available online: http://www.imo.org/OurWork/Safety/Navigation/Pages/VesselTrafficServices.aspx), (2015)

9. H. Backer, J. Leppänen, A.C. Brusendorff, K. Forsius, M. Stankiewicz, J. Mehtonen, M. Pyhäläa, M. Laamanen, H. Paulomäki, N. Vlasov, T. Haaranen, Marine Pollution Bulletin 60, 5, 642-649 (2010)

10. A.S. Grzelakowski, Rozwój transportu morskiego w regionie Morza Battyckiego, Zeszyty Naukowe Akademii Morskiej w Gdyni, 67, 73-88 (2010)

11. M. Bogalecka, Journal of Management and Finance 3, 1, 574-584 (2012)

12. R. Aps, M. Fetissov, F. Goerlandt, J. Helferich, M. Kopti, P. Kujala, 3rd European STAMP Workshop, STAMP UE 2015, 64-73 (Procedia Engineering 128, 2015)

13. IMO, Designation of the Baltic Sea area as a particularly sensitive sea area. Resolution MEPC, 136, 53 (2005)

14. R. Aps, M. Fetissov, F. Goerlandt, P. Kujala, A. Piel, 4th European STAMP Workshop 2016, 2-12 (Procedia Engineering 179, 2017)

15. J. Nordström, F. Goerlandt, J. Sarsama, P. Leppänen, M. Nissilä, P. Ruponen, T. Lübcke, S. Sonninen, Vessel TRIAGE, Safety Science 85, 117-129 (2016)

16. MAIB, 2009, Report on the Investigation into the Flooding and Foundering of the Grab Hopper Dredger Abigail H in the Port of Heysham 2 November 2008 (Marine Accident Investigation Branch, Southampton, UK, 2009)

17. MIT, 2013, Cruise Ship Costa Concordia Marine Casualty on January 13, 2012 Report on the Safety Technical Investigation. Ministry of Infrastructures and Transports (2013)

18. MAIB, 2015, Report on the Investigation of the Grounding and Flooding of the ro-ro ferry Commodore Clipper in the Approaches to St Peter Port, Guernsey on 14 July 2014 (Marine Accident Investigation Branch, Southampton, UK, 2015)

19. P. Luokkala, K. Virrantaus, Safety Science 63, 191-203 (2014)

20. H. Seppänen, K. Virrantaus, Safety Science 77, 112-122 (2015)

21. Z. Kopacz, W. Morgaś, J. Urbański, Zeszyty Naukowe Akademii Marynarki Wojennej w Gdyni 169, 2, 41-58 (2007) 
22. T. Szubrycht, K. Rokiciński, Gospodarka morska w świetle wybranych zagrożeń współczesnego świata (AMW, Gdynia, Poland, 2006)

23. K. Marcjan, L. Gucma, Wykorzystanie analizy incydentów nawigacyjnych $w$ celu oceny bezpieczeństwa nawigacyjnego na obszarach Morza Bałtyckiego o dużym zagęszczeniu ruchu statków, Prace Naukowe Politechniki Warszawskiej - Transport 102, 77-86 (Politechnika Warszawska, Poland, 2014)

24. Annual report on shipping accidents in the Baltic Sea area during 2012, Baltic Marine Environment Protection Commission (HELCOM, 2012)

25. Statistical Yearbook of Maritime Economy (Warsaw-Szczecin, Poland, 2015)

26. Statistical Yearbook of Maritime Economy (Warsaw-Szczecin, Poland, 2014)

27. Statistical Yearbook of Maritime Economy (Warsaw-Szczecin, Poland, 2016)

28. A. Marczuk, J. Caban, P. Savinykh, N. Turubanov, D. Zyryanov, Maintenance Reliability 19, 1, 121-125 (2017)

29. J. Lizbetin, O. Stopka, ICTTE - 3rd International Conference on Traffic and Transport Engineering, 382-387 (Belgrade, Serbia, 2016) 